Journal of Physical Science, Vol. 29(Supp. 2), 185-194, 2018

\title{
Physical Properties of Edible Sorgum Starch Film Added with Carboxymethyl Cellulose
}

\author{
Rr. Dewi Artanti Putri, ${ }^{*}$ Aji Setiawan and Puji Diah Anggraini \\ Department of Chemical Engineering, Engineering Faculty, Universitas Negeri \\ Semarang, Semarang 50229, Indonesia
}

*Corresponding author: dewi.artanti@mail.unnes.ac.id

Published online: 30 July 2018

To cite this article: Putri, R. D. A, Setiawan, A. \& Anggraini, P. D. (2018). Physical properties of edible sorgum starch film added with carboxymethyl cellulose. J. Phys. Sci., 29(Supp. 2), 185-194, https://doi.org/10.21315/jps2018.29.s2.14

To link to this article: https://doi.org/10.21315/jps2018.29.s2.14

\begin{abstract}
Edible films have been widely used in food packaging. One of the basic materials of these edible films is starch. One potential source of starch is sorghum which contains $72 \%$ starch. However, generally starch-based edible film which contains amylopectin has some weaknesses such as being fragile, easily broken and less flexible. Carboxymethyl cellulose (CMC), a cellulose derivative product, is expected to improve the mechanical properties of starch-based edible film. The objective of this work is to study the physical properties of sorgum flour film and the effect of CMC as an additive in the characteristic of edible film biopolymers that produce sorghum flour. The study was started with the production of sorghum starch, and then synthesised with the addition of CMC starch $(0 \%, 5 \%, 10 \%, 15 \%, 20 \%$ and $25 \% \mathrm{w} / \mathrm{w})$, and finally the mechanical characterisation and Fourier transform infrared (FTIR) analysis. The tensile test results showed that the addition of CMC has affected the tensile strength, elongation and elasticity. The lowest level of tensile strength was at $7.742 \mathrm{MPa}$ at $0 \%$ of CMC concentration and the highest level was at $29.988 \mathrm{MPa}$ with CMC concentration of $10 \%$. The addition of CMC to the film also affected the elongation properties of the sorghum film. The lowest level of elongation of the film was $14 \%$ at $0 \%$ of CMC concentration and the highest one was $65 \%$ at $25 \%$ of CMC concentration. The addition of CMC also affected the elasticity of the sorghum film. The lowest elasticity level was $3.1 \mathrm{~mm}$ at $0 \%$ of CMC concentration and the highest level one was $5.2 \mathrm{~mm}$ at $25 \%$ of CMC concentration. Whereas, the FTIR analysis results showed that the addition of CMC did not form any new group, which means that the synthesis process occurred only physically.
\end{abstract}

Keywords: Edible films, sorghum starch, $\mathrm{CMC}$, physical properties, carboxymethyl cellulose

(C) Penerbit Universiti Sains Malaysia, 2018. This work is licensed under the terms of the Creative Commons Attribution (CC BY) (http://creativecommons.org/licenses/by/4.0/). 


\section{INTRODUCTION}

Edible film is an edible thin layer used to coat foodstuff. ${ }^{1}$ Its use in wrapping improves the quality of food, prolongs the shelf life, increases the food's economic efficiency, and inhibits the displacement of water vapour. ${ }^{2}$ Other advantages of using edible films include: ability of food to be consumed directly with the packaged products; do not pollute the environment; improve organoleptic properties for packaged products; and act as antimicrobial and antioxidant substances. ${ }^{3}$ The initial use of edible film as food packaging is to reduce the use of synthetic plastics and minimise environmental pollution. Hydrocolloids that can be used to make edible films are proteins (gel, casein, soy protein, corn protein and wheat gluten) and carbohydrates (starch, alginate, pectin, Arabic gum and other carbohydrate modifications), whereas the lipids used are wax, glycerol and fatty acids. ${ }^{4}$ Several studies have been reported on the utilisation of starch from various sources such as corn, yam, pea starch, cassava starch, banana peel and sorgum to synthesise coatings and films. ${ }^{5-10}$ Starch is a polymer type of polysaccharide that has an important role in the manufacture of biodegradable films since it has the easy nature of forming a continuous matrix and its abundant availability in nature, hence it is appropriate if various starch sources are explored for the synthesis of edible film. ${ }^{5}$ One potential source of starch is sorghum, which contains $72 \%$ starch. ${ }^{11}$ However, generally starch-based edible film containing amylopectin has some weaknesses such as fragile, easily broken and less flexible. ${ }^{6}$ To overcome these weaknesses, improving the chemical and functional characteristics of starch by modifying it can become a solution.

Carboxymethyl cellulose (CMC) is a cellulose ether which can show gelation performance by heating and forming an excellent film because of its polymer chain structure and its high molecular weight. Thus, the nature of $\mathrm{CMC}$ is expected to improve the mechanical characteristics of the starch-based edible film. Due to the similar chemical properties between $\mathrm{CMC}$ and starch, it is expected to give good results. ${ }^{7}$ Reviews of the addition of CMC on starch-based edible film production have been conducted by Putri et al., Ghanbarzadeh et al. and Wirongrong et al. which examined the effects of CMC on the hydrophobicity property of sorghum edible film. ${ }^{4,5,8}$ The results showed that $\mathrm{CMC}$ can decrease the filtration of water by the film up to $65.8 \%$ with the addition of $25 \%$ (w/w starch) CMC. The quality and use of edible film is determined by several physical properties such as thickness, elongation and tensile strength. ${ }^{12}$ Accordingly, this study will examine the effect of $\mathrm{CMC}$ on edible film characteristics of sorghum starch. 


\section{EXPERIMENTAL}

\subsection{Materials}

In this study, raw materials of red sorghum flour were obtained from Ganesha Farmhouse, Bandung, Indonesia. Glycerol as plasticiser was obtained from Merck, which is calcium nitrate (desiccator). The CMC was obtained from Indrasari Chemical Store, Semarang, Indonesia. Whereas, citric acid as preservative and colour film, as well as the distilled water were supplied by Chemical Engineering Integrated Laboratory of Universitas Negeri Semarang, Indonesia. ${ }^{9}$

\subsection{Sorgum Starch Preparation}

The process of making sorghum starch was done with sorghum flour as a main ingredient. The flour was soaked for $24 \mathrm{~h}$. After that, it was rinsed with water, drained, and then filtered and pressed. The filtered water was deposited for $4 \mathrm{~h}$ until it became starch. If necessary, the starch would be washed twice until its colour turned white. The starch was then dried under the sun for 2 to 3 days. ${ }^{13}$

\subsection{Film Synthesis}

The edible film synthesis was made by using the method in Ghanbarzadeh et al. by mixing $5 \mathrm{~g}$ of starch with $100 \mathrm{ml}$ of distilled water, glycerol $(40 \mathrm{ml} / 100 \mathrm{~g}$ of starch), and 0.5 citric acid $\left(10 \% \mathrm{w} / \mathrm{w}\right.$ of starch) for $5 \mathrm{~min}$ at a temperature of $25^{\circ} \mathrm{C} .{ }^{5}$ Afterwards, the suspension was stirred using a magnetic stirrer (500 rpm) for $30 \mathrm{~min}$ in a water bath at a temperature of $90^{\circ} \mathrm{C}$. The $\mathrm{CMC}$ at several concentrations $(5 \%, 10 \%, 15 \%, 20 \%$ and $25 \% \mathrm{w} / \mathrm{w}$ starch) were dissolved in $75 \mathrm{ml}$ of distilled water at $75^{\circ} \mathrm{C}$ for $10 \mathrm{~min}$. The suspension of starch and mixed CMC solution $\left(75 \mathrm{ml} \mathrm{CMC}+100 \mathrm{ml}\right.$ of starch, citrate acid and glycerol) was stirred at $75^{\circ} \mathrm{C}$ for $10 \mathrm{~min}(\mathrm{pH}=5.5)$. The dough was then cooled at $40^{\circ} \mathrm{C}$ and mixed gently for 20 min to remove all air bubbles. Afterward, about $70 \mathrm{ml}$ of dough was poured into an acrylic film maker and flattened in order to have same thickness (measured using a micrometer) and then dried at $60^{\circ} \mathrm{C}$ in an oven to make the layer stable.

\subsection{Mechanical Characterisation}

Mechanical characterisation of the film was done by tensile test. Three parameters studied are tensile strength, elongation and elasticity. The tests were conducted at the Integrated Laboratory of Diponegoro University, Semarang with the Brookfield Texture Profile Analyzer (TPA) tool. 


\section{RESULTS AND DISCUSSION}

\subsection{Tensile Strength}

Tensile strength can be defined as the maximum acceptable strain pressure of the sample. The effect of CMC addition on the tensile strength of sorghum film can be seen in Figure 1.

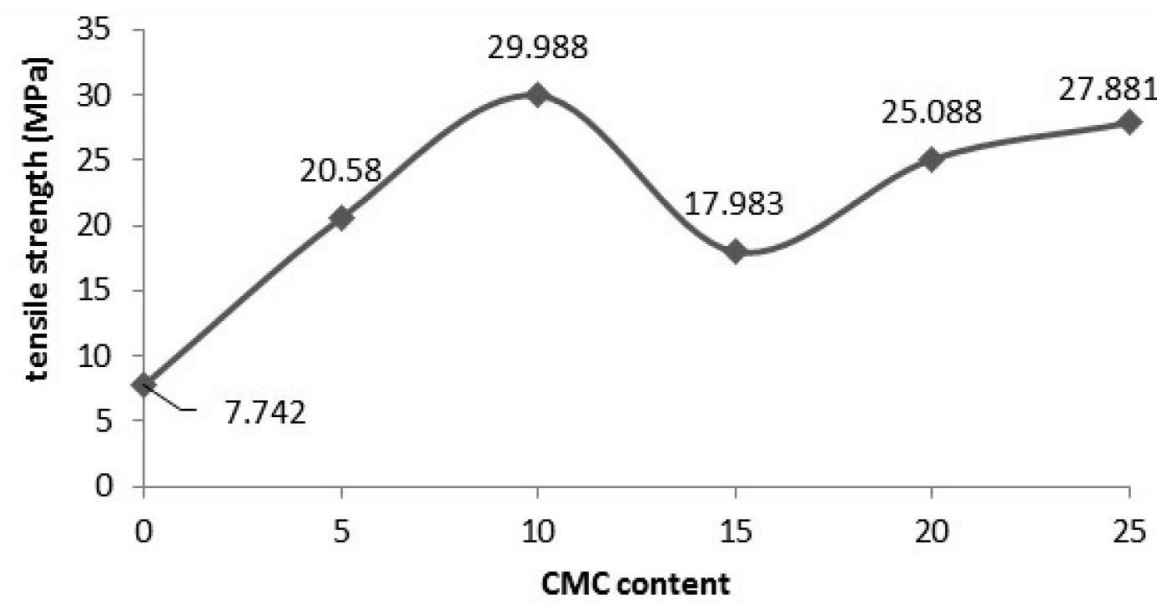

Figure 1: The effect of CMC on the tensile strength of the sorghum starch film.

Figure 1 shows that there was inconsistency effect with the addition of CMC in the film. The lowest yield of tensile strength was $7.742 \mathrm{MPa}$ at $\%$ CMC concentration and the highest level was $29.988 \mathrm{MPa}$ with $10 \% \mathrm{CMC}$ concentration. The mechanical properties are influenced by the components of a film. In this study, the starch was used as its constituent matrix, CMC as a supporting biopolymer and plasticiser is glycerol. The effect of adding CMC will certainly provide different mechanical properties. Starch as a matrix has poor mechanical properties. The addition of biopolymer is expected to improve the mechanical properties of a film due to the increasing affinity in the film. ${ }^{10}$ Ban stated that a factor affecting the mechanical properties of a film is the affinity among its constituent components. ${ }^{14}$ Affinity itself is a phenomenon in which certain atoms or molecules have a tendency to unite and bind. As the affinity value increases, the more bonding between molecules occurs and the strength of a material is affected by the chemical bonds of the constituent. A strong chemical bond is influenced by the number of molecular bonds and the types of bond. From the results of this study, at concentrations of $5 \%$ and $15 \%$ CMC edible film produced close to LDPE type plastic characteristics. On the other hand, edible film using CMC 10\%, 20\% and 25\% characteristics approach 
HDPE plastic when viewed from the aspect of tensile strength. ${ }^{10}$ The increasing and decreasing of the tensile strength depend on the strength of the material used in the filmmaking, to form large and strong molecular bonds.

\subsection{Elongation}

According to Gennadios et al., an extension is determined from the point that will affect the film torn at the time of stretching. ${ }^{15}$ The length increases until the tear of the film shows an extension. The effect of adding $\mathrm{CMC}$ on the elongation properties of the film can be seen in the following Figure 2:

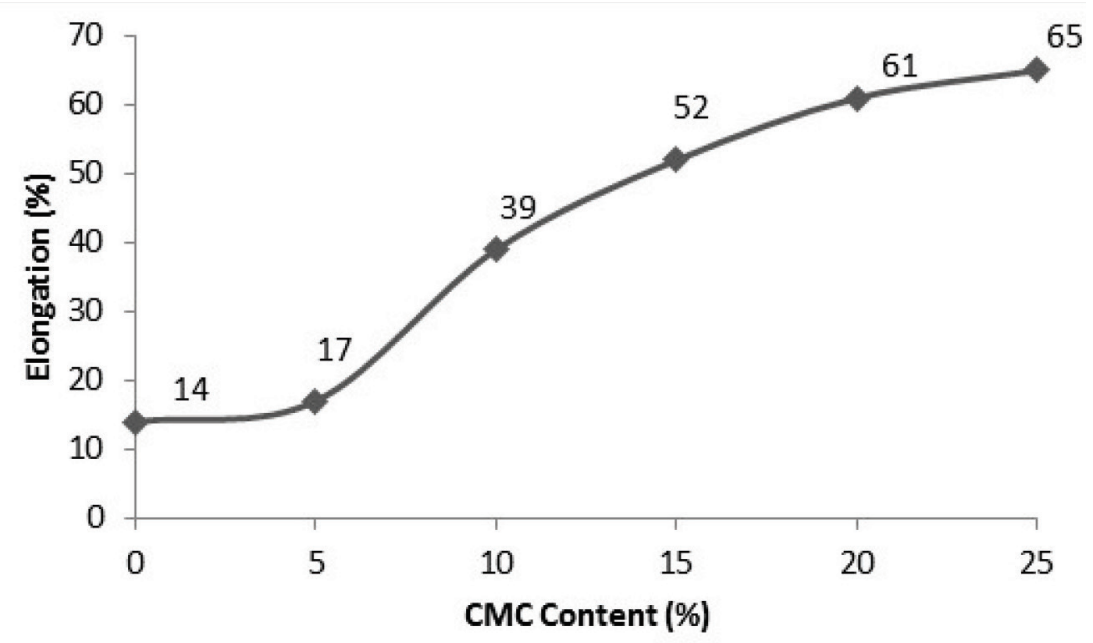

Figure 2: The effect of CMC addition on the film elongation properties.

Figure 2 shows increasing elongation with the $\mathrm{CMC}$ addition concentration to the sorghum film. The lowest percentage of elongation level in the film was $14 \%$ at $0 \%$ CMC concentration and the highest level was $65 \%$ at $25 \%$ CMC concentration. The graph also shows that the increase in CMC concentration will lead to an increasing tendency of elongation percentage of the film formed. The more $\mathrm{CMC}$ is added, the number of hydrogen bonds and electrostatic forces formed between CMC and sorghum seed flour will increase and the matrix texture that forms the edible film will become stronger and more compact. The CMC addition will increase the amount of carbon and functional groups in the matrix chain and increase the percentage of elongation. The $\mathrm{CMC}$ addition is proven in improving the mechanical properties of the film. Diredja reported that without the addition of $\mathrm{CMC}$, the soybean meal film produced is fragile, not compact, and difficult to be removed from the slab. ${ }^{16}$ 


\subsection{Elasticity}

The elasticity phenomenon can be seen in Figure 3 where the addition of CMC concentration affects the affinity of the sorghum film. The more $\mathrm{CMC}$ concentration is added, the greater the tendency of molecules in the film to unite and this results in a strong chemical bond. This phenomenon that occurs in the elasticity parameters of the film was shown in Figure 3 as follows:

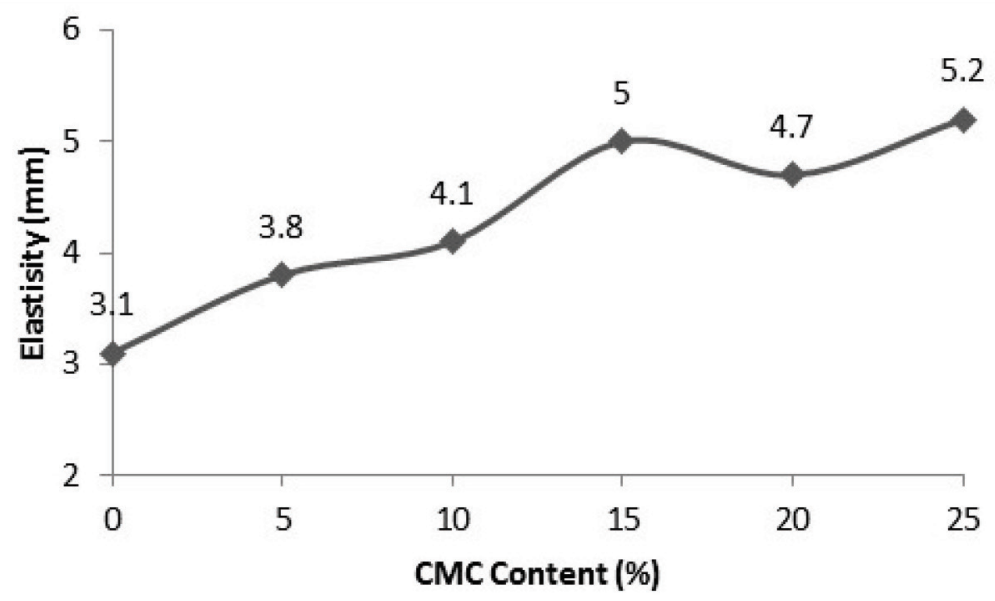

Figure 3: The influence of CMC concentration on the elasticity of sorghum film.

Elasticity is the ratio of tensile strength to elongation. Measurement of elasticity has been done by Kusumawati in making edible film from corn starch which yields decreasing elasticity. ${ }^{17}$ The best result that can be seen from Figure 3 is addition of $25 \% \mathrm{CMC}$ with $5.2 \mathrm{~mm}$ value. The lowest elasticity point is $3.1 \mathrm{~mm}$ at $0 \%$ $\mathrm{CMC}$ concentration. It shows that adding $\mathrm{CMC}$ concentration will increase the film elasticity due to the influence of molecular affinity in the film.

\subsection{Functional Group Analysis}

Functional group testing is performed with the FTIR spectrophotometer. This analysis aims to determine the functional group changes of a material or matrix produced. This test was performed on an edible film sample with a film without addition of $\mathrm{CMC}$ and with $25 \%$ addition of CMC. The results of FTIR edible film characteristics without addition of CMC and edible film with the addition of CMC by $10 \%$ can be seen in Figure 4 . 


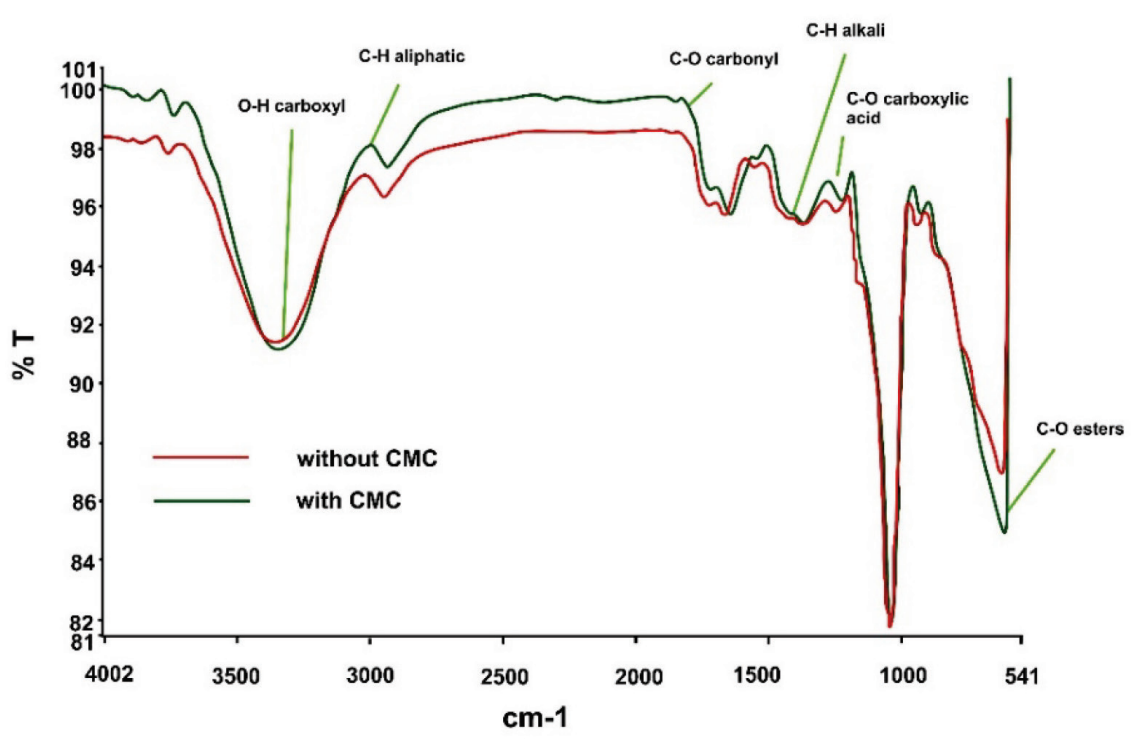

Figure 4: FTIR analysis of sorghum starch edible film.

The results of FTIR edible film characteristics of sorghum starch without CMC addition shows that the peak wave number (presented in Table 1) shows the presence of several peaks of wave numbers. It can be seen that carboxyl O-H and amines N-H are present in $3300 \mathrm{~s}$ wave numbers. Other peaks can also be seen with aliphatic $\mathrm{C}-\mathrm{H}$ at wave number $2800-2950 \mathrm{~nm}, \mathrm{C}=\mathrm{O}$ carbonyl is in wave number of $1700 \mathrm{~nm}$, and ester C-O is $1000 \mathrm{~nm}$ to $1150 \mathrm{~nm}$.

Furthermore, FTIR characteristic analysis was performed on edible film with the addition of CMC. The result of FTIR characteristics is presented in Table 2. The result of edible film group analysis of sorghum starch with the addition of CMC as presented in Table 2 shows several peaks of wave numbers. It can be seen that carboxyl O-H and amines N-H are present in $3300 \mathrm{~s}$ of wave number. Likewise, in other peaks, the aliphatic $\mathrm{C}-\mathrm{H}$ is in wavelength of $2800-2950 \mathrm{~nm}$, carbonyl $\mathrm{C}=\mathrm{O}$ is in $1700 \mathrm{~nm}$, the ester $\mathrm{C}-\mathrm{O}$ is in $1000 \mathrm{~nm}$ to $1150 \mathrm{~nm}$. The influence of the $\mathrm{CMC}$ addition lies in the range of $2300 \mathrm{~s}$ waves of $0 \% \mathrm{CMC}$ variable with a stretch due to bound $\mathrm{H}$ and $\mathrm{OH}$ stretch. It happens due to the bonding of starch group with glycerol without an adhesive between them. In addition, in variable $25 \%$ of present alkalo $\mathrm{C}=\mathrm{C}$ wave due to the presence of $\mathrm{CMC}$ gives reaction to starch and glycerol group. The material produced from the physical blending process due to the absence of a new functional group causes the bioplastic material still exhibiting hydrophilic properties (like water) as its constituent properties. The findings are in line with the research done by Darni and Utami in the study of the manufacture and 
characteristics of mechanical properties and bioplastic hydrofibity of the sorghum starch. ${ }^{10}$ By studying the interaction, it can be concluded that CMC can improve the mechanical properties of edible film by forming hydrogen bonds among chains so that the edible film becomes more tight and rigid. Other than that, it can also give effect of winding path for water molecule that passes through it. To reduce its stiffness, the addition of glycerol and the reduction of hydrogen interaction can be done in order the formed edible film is elastic. There are also carbonyl (CO) and esther $(\mathrm{COOH})$ functional groups on bioplastic materials tested using FTIR, so that these bioplastic materials can be degraded.

Table 1: FTIR functional group with $0 \%$ of CMC concentration.

\begin{tabular}{lll}
\hline $\mathrm{X}\left(\mathrm{cm}^{-1}\right)$ & $\mathrm{Y}(\% \mathrm{~T})$ & Functional group \\
\hline 3347.47 & 99.11 & O-H carboxyl \\
2934.20 & 96.89 & C-H aliphatic \\
1709.51 & 96.58 & C=O carbonyl \\
1648.78 & 96.17 & C=O carbonyl \\
1354.11 & 95.78 & C-H alkanes \\
1226.89 & 96.34 & C-O carboxylic acid \\
1026.09 & 79.3 & C-O esther \\
\hline
\end{tabular}

Table 2: FTIR functional group with $25 \%$ of CMC concentration.

\begin{tabular}{lll}
\hline $\mathrm{X}\left(\mathrm{cm}^{-1}\right)$ & $\mathrm{Y}(\% \mathrm{~T})$ & Functional Group \\
\hline 3353.42 & 91.13 & O-H carboxyl \\
2936.47 & 97.38 & $\mathrm{C}-\mathrm{H}$ aliphatic \\
1717 & 96.58 & $\mathrm{C}=\mathrm{O}$ carbonyl \\
1644.86 & 95.71 & $\mathrm{C}=\mathrm{O}$ carbonyl \\
1367.3 & 95.46 & $\mathrm{C}-\mathrm{H}$ alkanes \\
1224.27 & 96.22 & C-O carboxylic acid \\
1030.09 & 81.83 & C-O esther \\
\hline
\end{tabular}

\section{CONCLUSION}

The addition of $\mathrm{CMC}$ to the film affects tensile strength of sorghum film. The lowest level of tensile strength is at $7.742 \mathrm{MPa}$ at $0 \% \mathrm{CMC}$ concentration and the highest level is at $29.988 \mathrm{MPa}$ with CMC concentration of $10 \%$. The addition of CMC to 
the film will affect the elongation properties of the sorghum film. The lowest level of elongation percentage in the film is $14 \%$ at $0 \%$ of CMC concentration and the highest level is $65 \%$ at $25 \%$ of CMC concentration. The addition of CMC to the film affects the elasticity of the sorghum film. The lowest elasticity level is $3.1 \mathrm{~mm}$ at $0 \%$ of $\mathrm{CMC}$ concentration and the highest level of sorghum film elasticity is 5.2 $\mathrm{mm}$ at $25 \%$ of CMC concentration. From the result of FTIR analysis it is found that addition of $\mathrm{CMC}$ does not form any new group which means that the process only occurs physically.

\section{ACKNOWLEDGEMENTS}

The authors thank colleagues of Universitas Negeri Semarang, especially Lilis Novitasari et al. for assisting in this research. This research was funded by Daftar Isian Pelaksanaan Anggaran (DIPA) Penerimaan Negara Bukan Pajak (PNBP) Universitas Negeri Semarang, no. DIPA-042.01.2.400899/2016 and DIPA042.01.2.400899/2017. The supports all rendered assistance and encouragement throughout the research work.

\section{REFERENCES}

1. Lin, D. \& Zhao, Y. (2007). Innovations in the development and application of coatings for fresh and minimally processed fruits and vegetables. CRFSFS, 6(3), 60-75, https://doi.org/10.1111/j.1541-4337.2007.00018.x.

2. Winarti, C. M. \& Widaningrum. (2012). Teknologi produksi dan aplikasi pengemas edible film antimikroba berbasis pati. J. Litbang Pert., 31(3), 85-93.

3. Murdianto, W. (2005). Sifat fisik dan mekanik edible film dari ekstrak daun janggelan (Mesona palustris Bl.). JTP, 1(1), 8-13.

4. Putri, R. D. A., Setiawan, A. \& Anggraini, P. D. (2016). Effect of carboxymethyl cellulose (CMC) as biopolymers to the edible film sorghum starch hydrophobicity characteristics. Paper presented at the AIP Conference Proceedings, Semarang, Indonesia, 5-6 October, 020044-1-020044-5.

5. Ghanbarzadeh, B., Almasi, H. \& Entezami, A. A. (2010). Physical properties of edible modified starch/carboxymethyl cellulose films. Elsev. IFSET., 11 (4), 697-702, https://doi.org/10.1016/j.ifset.2010.06.001.

6. Mali, S. et al. (2005). Mechanical and thermal properties of yam starch films. Food Hydrocol., 19, 157-164, https://doi.org/10.1016/j. foodhyd.2004.05.002. 
7. Ma,X., Chang, P. R. \& Yu, J. (2008). Properties of biodegradable thermoplastic pea starch/carboxymethyl cellulose and pea starch/microcrystalline cellulose composites. Carbohydr. Polym., 72(3), 369-375, https://doi.org/10.1016/j. carbpol.2007.09.002.

8. Wirongrong, T. et al. (2011). Effect of carboxymethyl cellulose concentration on physical properties of biodegradable cassava starch-based films. Chem. Cent. J., 5(6), 2-8.

9. Hardjono et al. (2016). Pengaruh penambahan asam sitrat terhadap karakteristik film plastik biodegradable dari pati kulit pisang kepok (Musa acuminata balbisiana colla). JBAT, 5(1), 22-28.

10. Darni, Y. \& Utami, H. (2010). Studi pembuatan dan karakteristik sifat mekanik dan hidrofobitas bioplastik dari pati sorgum. J. Reka. Kim. Ling., 7(4), 88-93.

11. Sirappa, M. P. (2003). Prospek pengembangan sorgum di Indonesia sebagai komoditas alternatif untuk pangan, pakan, dan industri. J. Litbang Pert., 22(4), 133-140.

12. Huse, M. A, Wignyanto \& Dewi, I. A. (2014). Aplikasi edible coating dari karagenan dan gliserol untuk mengurangi penurunan kerusakan apel romebeauty. Unpublished undergraduate report, Universitas Brawijaya, Indonesia.

13. Mardawati, E. (2011). Sorghum disosoh beragam olahan didapat. Trubus, 28(2). Retrieved 17 March 2016 from http://www.trubus-online.co.id/ sorgum-disosoh-beragam-olahan-didapat.

14. Ban, W. et al. (2005). Improving the physical and chemical functionally of starch-derived films with biopolymers. J. Appl. Polym. Sci., 100(3), 25422548, https://doi.org/10.1002/app.23698.

15. Gennadios, A. et al. (1993). Effect of PH on properties wheat gluten and soy protein isolated film. J. Agric. Food Chem., 41(11), 1835-1893, https://doi. org/10.1021/jf00035a006.

16. Diredja, D. (1996). Mempelajari pengaruh penambahan sodium karboksimetilselulosa terhadap karakteristik edible film dari protein bungkil kedelai. Bogor: Fateta.

17. Kusumawati, D. H. (2013). Karakteristik fisik dan kimia edible film pati jagung yang diinkoporasi dengan perasan temu hitam. JPA, 1(1), 90-100. 